\title{
PENGARUH PEMBERIAN PISANG AMBON (Musa Paradisiaca S) TERHADAP PENURUNAN TEKANAN DARAH PADA LANSIA PENDERITA HIPERTENSI
}

Siti Fatmawati ${ }^{1}$, Hepti Muliyati ${ }^{1}$, Sukrang ${ }^{1}$ Program Studi Ilmu Keperawatan, STIKes Widya Nusantara Palu ${ }^{1}$

Kutipan:Fatmawati, S., Muliyati, H., Sukrang. (2017). The Effect of Ambon Banana Administering (Musa Paradisiaca S) Toward Reducing of Blood Pressure for Elderly in Hypertension . JurnalKeperawatanMuhammadiyah, 2 (2)

Korespondensi
st.fatmawati12@gmail.com $\begin{aligned} & \text { Odministering (Musa Paradisiaca S) toward reducing of } \\ & \text { blood pressure of elderly in hypertension. }\end{aligned}$

Methods: This article is quatitative research with pre experiment design (pre and post test without control). The population of this research is all the elderly who live in Social House of Tresna Werda Al Kautsar Foundation, Palu. Keywords: Ambon Banana, elderly, Hypertention The number of sample was 6 elderly and taken by total sampling technique that done from 1 to 7 August 2017. Statistict test by wilcoxon signed test.

Results: The result of this research shown that have decreasing of Blood Pressure after giving therapy of Ambon Banana about 3 pieces (303 gram) a day within one week. Decreasing of systole pressure about $25 \mathrm{mmHg}$ and diastole pressure 13,34 $\mathrm{mmHg}$ with $p$ value $=0,023$ $(p<0,05)$.

Conclusion: Administering of Ambon banana have effect toward decreasing of blood pressurefor elderly in Hypertension at Social House of Tresna Werda Al Kautsar Foundation, Palu.

\section{PENDAHULUAN}

Lanjut usia (lansia) merupakan kelompok penduduk yang berumur 60 tahun atau lebih (WHO, 2015). Secara global proporsi populasi penduduk berusia lebih dari 60 tahun pada tahun 2014 adalah 12\% dari total populasi global (UNFPA, 2015). Jumlah populasi lansia berusia lebih dari 60 tahun di Indonesia mengalami peningkatan setiap tahun yaitu 19.142.805 jiwa tahun 2014 menjadi 21.685.326 jiwa tahun 2015 (Kemenkes, 2015). Sulawesi Tengah juga terjadi peningkatan yaitu 196.962 jiwa tahun 2014 menjadi 200.121 jiwa tahun 2015 (BPS Sulteng, 2015). Jumlah lansia di Kota Palu yaitu 18.176 pada tahun 2014 dan 18.133 pada tahun 2015(BPS Kota Palu, 2015).

Meningkatnya populasi lansia ditandai dengan usia harapan hidup yang semakin meningkat dari tahun ke tahun. Usia harapan hidup lansia di Indonesia pada tahun 2013 adalah 70,07 tahun, angka ini meningkat menjadi 70,59 tahun pada tahun 2014 dan 70,78 tahun pada tahun 2015 . Usia harapan hidup lansia di Sulawesi 
Tengah pada tahun 2013 adalah 67,02 tahun, dan naik menjadi 67,18 tahun pada tahun 2014 serta pada tahun 2015 menjadi 67,26 tahun (BPS, 2015). Usia harapan hidup lansia di Kota Palu pada tiga tahun terakhir (tahun 2013-2015) tidak mengalami peningkatan yaitu 69,93 tahun (BPS, 2015b).

$$
\text { Fungsi fisiologis mengalami }
$$

penurunan seiring dengan bertambahnya usia akibat proses penuaan sehingga penyakit tidak menular banyak muncul pada lanjut usia. Selain itu masalah degeneratif menurunkan daya tahan tubuh sehingga rentan terkena infeksi penyakit menular. Hasil Riset kesahatan dasar (Riskesdas) tahun 2013 menunjukkan bahwa penyakit terbanyak pada lanjut usia adalah penyakit tidak menular antara lain hipertensi, artritis, stroke, Penyakit Paru Obstruktif Kronik (PPOK) dan Diabetes Mellitus (Kemenkes, 2016).

Hipertensi merupakan salah satu faktor risiko utama kematian di seluruh dunia, diperkirakan sekitar 9,4 juta kematian disebabkan oleh hipertensi. Secara global, prevalensi hipertensi pada orang dewasa 18 tahun ke atas sekitar 22\% pada tahun 2014 (WHO, 2014). Berdasarkan hasil Riskesdas, prevalensi hipertensi di Indonesia pada lansia yang berusia 55-64 tahun sebesar 53,7\%, usia 65-74 tahun sebesar $63,5 \%$, dan pada lansia 75 tahun ke atas sebesar 73,5\% di tahun 2007 (Depkes, 2008). Prevalensi tersebut mengalami penurunan pada tahun 2013 yaitu usia 5564 tahun sebesar $45,9 \%$, usia 65-74 sebesar $57,6 \%$ dan lansia berusia 75 tahun ke atas sebesar 63,8\% (Kemenkes, 2014). Meskipun prevalensi hipertensi pada lansia secara nasional mengalami penurunan, namun prevalensi hipertensi di Sulawesi Tengah masih mengalami peningkatan yaitu 28,7\% pada tahun 2007 (Depkes, 2008) menjadi $36,6 \%$ pada tahun 2013 (Kemenkes, 2014b).

Faktor yang turut berperan dalam meningkatnya prevalensi penyakit hipertensi pada lansia dari segi gizi adalah asupan kalium yang kurang adekuat dan asupan natrium yang tidak sesuai dengan rekomendasi jumlah yang harus dikonsumsi perhari oleh lansia. Ketidakadekuatan asupan kalium dikarenakan berkurangnya efisiensi absorpsi dan metabolisme disebabkan penurunan fungsi saluran pencernaan pada lansia. Hal inilah yang menyebabkan kebutuhan kalium lansia menjadi meningkat atau minimal sama dengan dewasa muda (Barasi, 2009). Kebutuhan kalium menurut umur angka kecukupan gizi lansia 60 tahun keatas dianjurkan untuk mengonsumsi kalium $4700 \mathrm{mg}$ perhari (Kemenkes, 2014a).

Terdapat bukti bahwa orang yang kurang mengonsumsi kalium memiliki tekanan darah yang lebih tinggi, sedangkan mereka yang mengonsumsi makanan tinggi kalium memiliki tekanan darah pada rentang normal. Makanan yang mengandung kalium yang tinggi adalah buah-buahan dan sayur-sayuran. Buah- buahan yang mengandung kalium yang tinggi adalah pisang, sehingga mengonsumsi pisang baik untuk menjaga kestabilan tekanan darah (Gunawan, 2005).

Berdasarkan hasil penelitian Dayanand et al. (2015) di Nepal penderita hipertensi yang mengonsumsi 2 buah pisang sehari mengalami penurunan tekanan darah secara signifikan yang disebabkan oleh kandungan kalium yang lebih tinggi pada pisang. Penelitian yang sama juga ditunjukkan oleh Tryastuti et al. (2012) bahwa penderita hipertensi berusia 60 75 tahun yang mengonsumsi 2 buah pisang ambon setiap hari mengalami penurunan tekanan darah, rata-rata penurunan tekanan darah sistolik adalah $11,70 \mathrm{mmHg}$ dan rata-rata penurunan tekanan darah diastolik adalah 3, $450 \mathrm{mmHg}$. Hasil penelitian 
Tangkilisan et al. (2013) juga menunjukkan terjadi penurunan tekanan darah setelah responden diberikan terapi diet pisang ambon sebanyak 3 buah sehari selama satu minggu, masing-masing penurunan rerata tekanan darah sistolik maupun diastolik ialah sebesar 9,545 $\mathrm{mmHg}$ dan 9,091 $\mathrm{mmHg}$.

Pisang ambon adalah pisang yang paling banyak disukai karena memiliki rasa yang lebih manis, tekstur yang lebih enak dan aroma yang lebih tajam jika dibandingkan dengan pisang yang dapat dimakan secara langsung lainnya. Pisang ambon telah banyak dikonsumsi oleh masyarakat tanpa memiliki efek samping. Selain itu pisang ambon memiliki kandungan kalium lebih tinggi dan natrium lebih rendah dibandingkan dengan buah pisang lainnya, dalam $100 \mathrm{~g}$ pisang ambon mengandung $435 \mathrm{mg}$ kalium dan hanya 18 mg natrium, sedangkan berat rata-rata satu buah pisang ambon $\pm 140 \mathrm{~g}$, sehingga dalam satu buah pisang ambon mengandung $\pm 600 \mathrm{mg}$ kalium dengan demikian pisang ambon menjadi alternatif dalam peningkatan asupan kalium khususnya pada lansia (Almatsier, 2004).

Lansia penderita hipertensi di Panti Sosial Tresna Werda Yayasan Al Kautsar Palu memiliki frekuensi makan tiga kali sehari dengan menu makan homogen atau sama per individu, sehingga pengontrolan konsumsi makanan pada lansia penderita hipertensi menjadi lebih mudah. Selain itu, pengontrolan tekanan darah pada lansia penderita hipertensi oleh tenaga kesehatan masih kurang terkontrol dengan baik ini, mengakibatkan tekanan darah pada lansia penderita hipertensi tidak terjadi penurunan yang signifikan dan tidak adanya penanganan terapi non farmakologi untuk penderita hipertensi.

Tujuan dari penelitian ini adalah menganalisis pengaruh pemberian pisang ambon (Musa Paradisiaca S) terhadap penurunan tekanan darah pada lansia penderita hipertensi di Panti Sosial Tresna
Werda Yayasan Al-Kautsar

Palu.

\section{METODE}

Penelitian ini menggunakan desain penelitian pra eksperimen (Pre and post test without control). Waktu penelitian dilakukan pada tanggal 01 sampai dengan 07 Agustus 2017. Populasi dalam penelitian ini adalah semua lansia yang tinggal di Panti Sosial Tresna Werda Yayasan Al Kautsar Palu. Teknik pengambilan sampel menggunakan total sampling, sehingga sampel dalam penelitian ini berjumlah 6 orang. Sampel diambil berdasarkan kriteria inklusi yaitu repsonden yang berusia $\geq 60$ tahun, memiliki tekanan darah $\geq 140 / 90$ $\mathrm{mmHg}$, dan bersedia menjadi responden. Kriteria ekslusi untuk penelitian ini yaitu responden yang memiliki penyakit komplikasi dan yang mengonsumsi obat anti hipertensi.

Pisang Ambon diberikan sebanyak 3 buah sehari atau setara dengan $303 \mathrm{gr}$ (pagi, siang, dan sore) selama seminggu. Instrumen penelitian yang digunakan adalah kuesioner untuk mengetahui karakteristik responden; sphygmomanometer dan stetoskop untuk mengukur tekanan darah responden. Analisis data menggunakan analisis univariat dan bivariat. Analisis bivariat menggunakan Wilcoxon Sign Test dengan tingkat signifikansi $\alpha \leq 0,05$. Sebagai uji prasyarat dilakukan uji normalitas pada data sistolik dan diastolik baik pre dan post.

HASIL

Karakteristik Responden

Karakteristik responden pada penelitian ini meliputi umur, jenis kelamin, dan pendidikan. 
Tabel 1. Karakteristik Responden Berdasarkan Umur, Jenis Kelamin, dan Pendidikan di Panti Sosial Tresna Werda Yayasan Al Kautsar Palu

\begin{tabular}{llcc}
\hline Karakteristik Responden & n & \% \\
\hline Umur & $60-74$ & 3 & 50 \\
& $75-90$ & 3 & 50 \\
\hline Jenis & Jumlah & 6 & 100 \\
\hline Kelamin & Laki-laki & 0 & 0 \\
& Perempuan & 6 & 100 \\
\hline Pendidikan & Jumlah & 6 & 100 \\
& Tidak & 5 & 83,3 \\
& Sekolah & & \\
& SD & 1 & 16,7 \\
\hline & Jumlah & 6 & 100 \\
\hline
\end{tabular}

Berdasarkan Tabel 1 menujukkan bahwa dari 6 responden, kelompok umur 6074 tahun (elderly) berjumlah 3 responden (50\%), dan kelompok umur 75-90 tahun (old) berjumlah 3 responden $(50 \%)$, seluruh responden $(100 \%)$ berjenis kelamin perempuan, serta sebanyak 5 responden $(83,3 \%)$ tidak sekolah dan 1 responden $(16,7 \%)$ memiliki pendidikan SD.

\section{Tekanan Darah Sebelum Intervensi}

Tabel 2. Tekanan Darah Responden Sebelum Diberikan Pisang Ambon Di Panti Sosial Tresna Werda Yayasan Al Kautsar Palu

\begin{tabular}{lcc}
\hline Tekanan Darah & $\mathrm{n}$ & $\%$ \\
\hline Hipertensi Stadium 1 & 2 & 33,3 \\
$(140-159 / 90-99 \mathrm{mmHg})$ & 4 & 66,7 \\
Hipertensi Stadium 2 & & \\
$(160->180 / 100->110 \mathrm{mmHg})$ & & 100 \\
\hline Jumlah & 6 & 100 \\
\hline
\end{tabular}

Berdasarkan Tabel 2 menujukkan bahwa 6 responden, 2 responden $(33,3 \%)$ mengalami hipertensi stadium 1 dan 4 responden $(66,7 \%)$ mengalami hipertensi stadium 2.

\section{Tekanan Darah Setelah Intervensi}

Tabel 3. Tekanan Darah Responden Setelah Diberikan Pisang Ambon Di Panti Sosial Tresna Werda Yayasan Al Kautsar Palu

\begin{tabular}{lcc}
\hline Tekanan Darah & $\mathrm{n}$ & $\%$ \\
\hline $\begin{array}{l}\text { Prahipertensi } \\
(120-139 / 80-89 \mathrm{mmHg})\end{array}$ & 4 & 66,7 \\
$\begin{array}{l}\text { Hipertensi Stadium 1 } \\
(140-159 / 90-99 \mathrm{mmHg})\end{array}$ & 2 & 33,3 \\
$\begin{array}{l}\text { Hipertensi Stadium 2 } \\
(160->180 / 100->110 \mathrm{mmHg})\end{array}$ & 0 & 0 \\
\hline Jumlah & 6 & 100 \\
\hline
\end{tabular}

Berdasarkan Tabel 3 menujukkan bahwa dari 6 responden, 4 reponden $(66,7 \%)$ telah memiliki tekanan darah yang tergolong prahipertensi dan 2 responden $(33,3 \%)$ masih mengalami hipertensi stadium 1, sedangkan responden yang mengalami hipertensi stadium 2 tidak ada lagi ( $0 \%)$.

\section{Pengaruh Pemberian Pisang Ambon Terhadap Tekanan Darah}

Tabel 4. Pengaruh Pemberian Pisang Ambon Terhadap Penurunan Tekanan Darah pada Lansia Di Panti Sosial Tresna Werda Yayasan Al Kautsar Palu

\begin{tabular}{llll}
\hline Tekanan Darah & $\mathrm{n}$ & Mean & $\mathrm{SD}$ \\
\hline Sistolik Sebelum & 6 & 158,33 & 7,528 \\
Sistolik Sesudah & 6 & 133,33 & 5,164 \\
Diastolik Sebelum & 6 & 96,67 & 5,164 \\
Diastolik Sesudah & 6 & 83,33 & 5,164 \\
\hline$p$-value $=0,023$ & & & \\
\hline
\end{tabular}

Berdasarkan Tabel 4, hasil analisis menggunakan uji statistik Wilcoxon, diperoleh nilai p-value 0,023 $(p<0,05)$ yang berarti pemberian pisang ambon berpengaruh signifikan terhadap penurunan tekanan darah pada 
lansia penderita hipertensi di Panti Sosial Tresna Werda Yayasan Al Kautsar Palu.

\section{PEMBAHASAN}

Berdasarkan hasil uji Wilcoxon signed test diperoleh bahwa ada pengaruh pemberian pisang ambon terhadap penurunan tekanan darah pada lansia penderita hipertensi di Panti Sosial Tresna Werda Yayasan Al Kautsar Palu. Hasil penelitian yang dilakukan kepada 6 reponden dengan pemberian pisang ambon, rata-rata tekanan darah sistolik sebelum pemberian pisang ambon adalah $158.33 \mathrm{mmHg}$ dan rata-rata tekanan darah sistolik sesudah pemberian pisang ambon adalah $133.33 \mathrm{mmHg}$ (penurunan rata-rata tekanan darah sistolik sebesar $25 \mathrm{mmHg}$ ). Hal ini juga terjadi pada rata-rata tekanan darah diastolik sebelum dan sesudah pemberian pisang ambon adalah 96.67 $\mathrm{mmHg}$ dan $83.33 \mathrm{mmHg}$ (penurunan tekanan darah diastolik sebesar 13,34 $\mathrm{mmHg}$ ).

Hipertensi meningkat seiring dengan bertambahnya usia, hipertensi dapat memberikan efek negatif pada penderita apabila tidak ditangani secara serius. Banyak hal yang dilakukan untuk menangani masalah hipertensi salah satunya adalah terapi gizi berupa diet tinggi kalium yang termasuk dalam terapi nonfarmakologi.

Sebagian besar responden terjadi penurunan tekanan darah karena mengonsumsi pisang ambon sebanyak 3 buah $(303 \mathrm{mg}$ ) per hari (pagi, siang dan sore) selama seminggu. Penurunan ini disebabkan karena kombinasi kalium yang tinggi dan natrium yang rendah dalam pisang ambon yang berperan penting dalam menurunkan tekanan darah.

WHO (2012) merekomendasikan peningkatan asupan kalium dari makanan untuk mengurangi tekanan darah dan risiko penyakit kardiovaskuler, stroke dan penyakit jantung koroner. Asupan kalium yang disarankan yaitu sebesar $3510 \mathrm{mg} / \mathrm{hari}$, dan salah satu makanan yang mengandung tinggi kalium adalah pisang ambon, yaitu sekitar $435 \mathrm{mg} /$ hari. Dengan mengonsumsi kalium yang sesuai dengan rekomendasi tersebut dapat meniadi pelindung terhadap kondisi ini ${ }^{19}$.

Kandungan kalium dalam pisang ambon berpengaruh menurunkan tekanan darah, dikarenakan kalium bekerja mirip obat anti hipertensi di dalam tubuh manusia. Pisang ambon memiliki kandungan kalium yang dapat menyebabkan penghambatan pada Renin Angiotensin System juga menyebabkan terjadinya penurunan sekresi aldosterone, sehingga terjadi penurunan reabsoripsi natrium dan air di tubulus ginjal. Akibat dari mekanisme tersebut, maka terjadi peningkatan diuresis yang menyebabkan berkurangnya volume darah, sehingga tekanan darah pun menjadi turun (Puspaningtyas, 2008). Puspitaningtyas (2014) juga menyatakan bahwa pisang ambon memiliki kandungan kalium lebih tinggi yang dapat berkhasiat untuk membantu mengurangi risiko stroke dan menurunkan tekanan darah.

Penelitian Tryastuti et al. (2012) di Panti Sosial Tresna Werda Sabai Nan Aluih Sicincin juga diperoleh hasil bahwa mengonsumsi 2 buah pisang ambon sehari dapat menurunkan tekanan darah, rata-rata penurunan tekanan darah sistolik adalah 11,70 $\mathrm{mmHg}$ dan rata-rata penurunan tekanan darah diastolik adalah $3,45 \mathrm{mmHg}$. Penelitian yang sama juga dikemukakan oleh Tangkilisan et.al (2013) di Kota Bitung bahwa terjadi penurunan tekanan darah setelah responden diberikan terapi diet pisang ambon sebanyak 3 buah sehari selama seminggu, masing-masing penurunan rerata tekanan darah sistolik maupun diastolik ialah sebesar $9,545 \mathrm{mmHg}$ dan 9,091 mmHg (Tangkilisan, et al. 2013).

\section{KESIMPULAN}

$\begin{array}{lr}\text { Dari hasil penelitian } & \text { yang } \\ \text { dilakukan, disimpulkan bahwa } & \\ \text { a. Tekanan darah } & \text { lansia } \\ \text { sebelum diberikan pisang ambon }\end{array}$


(Musa Paradisiaca S) adalah tergolong hipertensi stadium 1 dan hipertensi stadium 2

b. Tekanan darah lansia sesudah diberikan pisang ambon (Musa Paradisiaca S) telah mengalami penurunan menjadi prahipertensi (120139/80-89 $\mathrm{mmHg}$ ) dan hipertensi stadium 1 (140-159/90-99 mmHg)

c. Pemberian pisang ambon (Musa Paradisiaca S) berpengaruh terhadap penurunan tekanan darah pada lansia penderita hipertensi di Panti Sosial Tresna Werda Yayasan Al Kautsar Palu.

\section{SARAN}

Saran dalam penelitian ini, yaitu pemberian pisang ambon merupakan terapi nonfarmakologi yang direkomendasikan bagi penderita hipertensi untuk menurunkan tekanan darah. Pisang ambon dapat diberikan 3 buah (303 gram) sehari untuk menurunkan tekanan darah sistolik sebesar $25 \mathrm{mmHg}$ dan diastolik 13,34 $\mathrm{mmHg}$.

\section{DAFTAR PUSTAKA}

Almatsier, S. (2004). Prinsip dasar ilmu gizi. Jakarta: PT.Gramedia Pustaka Utama

Barasi, M. (2009). At a glance : Ilmu gizi. Jakarta: Erlangga

[BPS Sulteng] Badan Pusat Statistik Provinsi Sulawesi Tengah. (2015). Jumlah populasi lansia di Sulawesi Tengah. Sulawesi Tengah : BPS Sulteng

[BPS Kota Palu] Badan Pusat Statistik Kota Palu. (2015a). Jumlah populasi lansia di Kota Palu. Palu: BPS Kota Palu

[BPS] Badan Pusat Statistik. (2015). Usia harapan hidup di Indonesia dan Sulawesi Tengah. Jakarta: BPS

[BPS Kota Palu] Badan Pusat Statistik Kota Palu. (2015b). Usia harapan hidup di Kota Palu. Palu: BPD Kota Palu

Dayanand, G., Sharma, A., Ahmed, M., Jyothi, PP., \& Roni M. (2015). Effect of banana on blood pressure of hypertensive: a cross sectional study from Pokhara Nepal. Medical Science, 3(2), 233-237

[Depkes RI] Departemen Kesehatan Republik Indonesia. (2008). Riset Kesehatan Dasar (Riskesdas 2007) Laporan Nasional 2007. Jakarta: Depkes RI

Gunawan. (2005). Hipertensi. Yogyakarta: Kanisius

[Kemenkes RI] Kementerian

Kesehatan Republik

Indonesia. (2014a). Angka kecukupan gizi yang dianjurkan bagi bangsa Indonesia. Jakarta: Kemenkes RI

[Kemenkes $\quad \mathrm{RI}] \quad$ Kementerian Kesehatan Republik Indonesia. (2014b). Riset Kesehatan Dasar 2013. Jakarta: Kemenkes RI

[Kemenkes RI] Kementerian Kesehatan Republik Indonesia. (2015). Profil Kesehatan Indonesia. Jakarta: Kemenkes RI

[Kemenkes $\quad \mathrm{RI}] \quad$ Kementerian Kesehatan Republik Indonesia. (2016). Situasi usia lanjut (Lansia) di Indonesia. Jakarta: Kemenkes RI

Palmer A, Williams B. (2007). Simple guide tekanan darah tinggi. Jakarta: Erlangga

Puspaningtyas. (2008). The miracle of fruits. Jakarta Selatan: PT.Agromedia Pustaka

Tangkilisan, L.R., Kalangi, S., \& Masi G. (2013). Pengaruh terapi diet pisang ambon (Musa Paradisiaca Var. Sapientum Linn) terhadap penurunan tekanan darah pada klien hipertensi di Kota Bitung. Ejournal Keperawatan (e-Kp), $1(1), 1-6$

Tryastuti, D. (2012). Pengaruh konsumsi pisang ambon (Musa Paradisiaca S) terhadap tekanan darah lansia penderita hipertensi sedang di Panti Sosial Tresna 
Werdhasabai Nan Aluih Sicincin.

Padang (ID) : Universitas Andalas

[WHO] World Health Organization. (2012). Guideline : Potassium intake for adults and children. Switzerland: WHO

[WHO] World Health Organization. (2014). A global brief on hypertension sillent killer, global public health crisis. Switzerland : WHO

[WHO] World Health Organization. (2015). Q\&As Hypertension. Switzerland: WHO

[UNFPA] United Nations fund for Population Activities. (2015). Ageing. New York: WHO 
